\title{
Diurnal circulations and their multi-scale interaction leading to rainfall over the South China Sea upstream of the Philippines during intraseasonal monsoon westerly wind bursts
}

\author{
Myung-Sook Park • Chang-Hoi Ho • \\ Jinwon Kim • Russell L. Elsberry
}

Received: 10 March 2010/Accepted: 27 September 2010/Published online: 26 October 2010

(C) The Author(s) 2010. This article is published with open access at Springerlink.com

\begin{abstract}
The morning diurnal precipitation maximum over the coastal sea upstream of the Philippines during intraseasonal westerly wind bursts is examined from observations and numerical model simulations. A welldefined case of precipitation and large-scale circulation over the coastal sea west of the Philippines during 17-27 June 2004 is selected as a representative case. The hypothesis is that the mesoscale diurnal circulation over the Philippines and a large-scale diurnal circulation that is induced by large-scale differential heating over Asian continent and the surrounding ocean interact to produce the offshore precipitation maximum during the morning. Three-hourly combined satellite microwave and infrared rainfall retrievals define the morning rainfall peak during this period, and then later the stratiform rain area extends toward the open sea. A control numerical simulation in which a grid-nudging four-dimensional data assimilation (FDDA) is applied to force the large-scale diurnal circulation represents reasonably well the morning rainfall maximum. An enhanced low-level convergence similar to
\end{abstract}

\section{C.-H. Ho ( $\square)$}

School of Earth and Environmental Sciences,

Seoul National University, Seoul, Korea

e-mail: hoch@cpl.snu.ac.kr

M.-S. Park · R. L. Elsberry

Department of Meteorology,

Naval Postgraduate School,

Monterey, CA, USA

e-mail: mpark@nps.edu

J. Kim

Department of Meteorology,

University of California in Los Angeles,

Berkeley, CA, USA observations is simulated due to the interaction of the localand large-scale diurnal circulations. The essential role of the local-scale diurnal circulation is illustrated in a sensitivity test in which the solar zenith angle is fixed at 7 am to suppress this diurnal circulation. The implication for climate diagnosis or modeling of such upstream coastal sea precipitation maxima is that the diurnal variations of both the local- and the large-scale circulations must be taken into consideration.

Keywords Diurnal rainfall - Westerly wind bursts . Intra-seasonal rainfall variability $\cdot$ South China Sea

\section{Introduction}

The tropical large-scale atmosphere has a prominent spectral peak in intraseasonal frequencies throughout the year (Madden and Julian 1972), and in boreal summer this includes a high frequency intraseasonal oscillation (ISO) with a period of 10-20 days as well as a 30-60 day period (Chen et al. 2000). When the two ISO modes are in phase, the large-scale monsoon westerly flows are much stronger than the seasonal means, which is called a westerly wind burst (WWB) event (Kiladis et al. 1994). Because of the 'southwesterly' transport of moisture from the equatorial ocean into the subtropical Asia, the WWB event of the ISO is characterized by a 'wet' phase, essentially with increased convective instability over a wide area in the subtropics. Thus, the primary convective feature is indicated by the prolonged "convective bursts" over the subtropical ocean (Chen et al. 2000).

Recently, Wang (2006) and Hoyos and Webster (2007) showed from high-resolution microwave satellite rain retrievals that precipitation maxima within those subtropical 
convective bursts are located "on upstream coastal sea ${ }^{1}$ rather than on open sea". Hoyos and Webster (2007) concluded that if climate models are to reproduce the observed seasonal monsoon rainfall structure, the intraseasonal variations of convective bursts and rainfall need to be well simulated and the effects of coastal rainy ranges must be well understood. Park et al. (2007) indicated that coastal rainfall is associated with more frequent deep convective systems with larger ice particles or graupel than convective systems over the open sea. Accordingly, large condensation and freezing heat release induces prominent upper-level divergent circulations that radiate outward, even toward the middle latitudes (Lau et al. 2000; Yoo et al. 2004).

Such a dynamic response in the subtropical coastal region has motivated studies on the underlying processes contributed to this rainfall maximum. Xie et al. (2006) used numerical models to show that large-scale westerlies impinging on a coastal mountain range induce a weakening of the westerlies and generate local convergence and then this leads to a rainfall maximum along the coast. These studies have emphasized the role of large-scale westerlies and its interaction with the local circulation via orographic forcing in precipitation processes. However, these numerical studies of the interaction of the large- and local-scale flows did not include diurnal variations of the flows.

Diurnal rainfall variations are considered have an important contribution to the rainfall accumulation during the WWBs of the ISO (Sui and Lau 1992). Because the rainfall falling on the surface is modulated by the differential heating between land and sea, forecasting the embedded diurnal variability has important implications in the energetics of the regional circulations and rainfall in the intraseasonal period (Chakraborty and Krishnamurti 2008). Accordingly, diagnosing the impacts of the diurnal rainfall process may increase understanding of the convective processes on the intraseasonal time scale. This is the topic of the current paper.

Many studies have used in situ and satellite observations to document the diurnal variation of rainfall along the upstream coastal sea during WWBs or similar background conditions (Houze et al. 1981; Chen and Takahashi 1995; Ho et al. 2008). Using ground-based radar, Houze et al. (1981) showed that the diurnal peak of offshore rainfall west of Borneo occurs around noon. Ho et al. (2008) used 8 years of microwave rain retrievals from the Tropical Rainfall Measuring Mission (TRMM) Precipitation Radar (PR) to show that a diurnal rainfall maximum over the South China Sea occurs in late morning off the west coast of the Philippines. These studies thus document a different timing of the diurnal precipitation maximum over the

\footnotetext{
${ }^{1}$ Examples of these coastal seas in Asia include Arabian Sea, the eastern tropical Indian Ocean, and the South China Sea.
}

coastal seas in contrast to the well-known late evening or early morning peak time over open oceans (Yang and Smith 2006).

Two horizontal scales of diurnal circulation have been suggested that may modulate the convective processes leading to the upstream coastal sea rainfall. The first mesoscale diurnal circulation occurs on a scale of tens of kilometers, and is essentially the local land-sea breeze circulation (Ramage 1952; Houze et al. 1981; Oki and Musiake 1994; Ohasawa et al. 2001; Mapes et al. 2003b; Mori et al. 2004; Ichikawa and Yasunari 2006; and many others). The second large-scale diurnal circulation occurs on the scale of thousands of kilometers (Krishnamurti and Kishtawal 2000; Chow and Chan 2009).

The mesoscale diurnal circulation mechanism is hypothesized to contribute to the diurnal variation of rainfall over the upstream coastal sea when the nighttime offshore breeze weakens the large-scale low-level flow and produces local offshore convergence ${ }^{2}$ that leads to convection and rainfall. While the mesoscale offshore breeze reaches maximum amplitude after midnight due to the maximum thermal contrast across the coast, the diurnal rainfall peak over the coastal sea occurs from early morning to noon. Houze et al. (1981) refer to this mesoscale offshore breeze as a land breeze induced by the relatively lower nighttime temperatures over land compared to the sea. Mapes et al. (2003b) argued that the nocturnal land breeze, which is much weaker than the daytime sea breeze, might not produce a strong offshore breeze. In the Mapes et al. (2003a) model, the relatively lower nighttime temperature over land (cold pool) compared to over the sea leads to gravity waves emanating from the coastal mountain due to the diurnally varying heat source, turbulent heat flux convergence, and downslope flow from the elevated terrain. Mori et al. (2004) showed that both the land breeze and gravity currents (produced by cold downdrafts from inland convective cloud during the previous afternoon) may interact with the large-scale, low-level flow to cause coastal convergence and lead to offshore rainfall. Although different interpretations have been given for the underlying physical processes for the mesoscale offshore breeze, these studies all considered the interaction between mesoscale dynamics (with diurnal variation) and the large-scale flow without the consideration of the diurnal variability in the large-scale flow.

This study also considers a diurnal variation of largescale circulation by large-scale differential heating and cooling that is attributed to inhomogeneities in radiation, surface, and topographic condition, and precipitation.

\footnotetext{
${ }^{2}$ Whereas Xie et al. (2006) discusses an offshore convergence between persistent large-scale westerlies and the mesoscale circulation, this study will consider the diurnal variations of the mesoscale circulation contributing to the offshore convergence.
} 
Krishnamurti and Kishtawal (2000) and Chow and Chan (2009) documented the diurnal variation of large-scale circulation over Asian continent, and suggested the significance of the Tibetan Plateau on the large-scale diurnal circulation. Wang (2006) pointed out that the diurnal variations of monsoon rainfall and hydrological process with accompanying atmospheric heating are also important, as well as the land-ocean surface thermal contrast and the topography, to induce diurnal variations of the largescale circulation. A regional climate model (RCM) simulation by Chow and Chan (2009); see their Fig. 5) showed diurnal large-scale westerly wind perturbations not only in vicinity of the continent, but also over the South China Sea.

This observational and numerical modeling study will explore the hypothesis that the morning heavy rainfall over the coastal sea upstream of the Philippines during a WWB event of ISO is due to the interaction of local- and largescale diurnal circulations. Since the South China Sea has the Asian continent to the west and north, and has steep coastal topography of the Philippines to the east, two diurnal circulations on different spatial scales could interact. Data, case selection, and numerical model experiments are described in Sect. 2. The daily mean rainfall and largescale circulation are described in Sect. 3, and the observed diurnal variations of rainfall and cloud are presented in Sect. 4. The model simulations of the observed diurnal variations and atmospheric response will be presented in Sect. 5. The underlying processes will be discussed based on the interpretation of the numerical model simulations, and concluding comments are given in Sect. 6.

\section{Data, case selection, and model description}

Rainfall and cloud distributions are examined with the TRMM Multi-satellite Precipitation Analysis (TMPA) and the infrared brightness temperatures (BT) from the Geostationary Operational Environmental Satellites (GOES)-9. The TMPA is available every $3 \mathrm{~h}$ with a $0.25^{\circ}$ lat. $\times 0.25^{\circ}$ long resolution between $50^{\circ} \mathrm{S}$ and $50^{\circ} \mathrm{N}$. This global rainfall product is derived by merging geostationary infrared (e.g., GOES-9) and polar-orbiting passive microwave (e.g., TRMM) observations, and rain gauge measurements (Huffman et al. 2007). The reliability of TMPA for the diurnal variations has been established by comparison with rain gauge data (Sapiano and Arkin 2009). During the study period, the GOES-9 provided hourly infrared BTs with $5 \mathrm{~km} \times 5 \mathrm{~km}$ horizontal resolution. As in Park et al. (2007), the infrared BT is considered as a proxy of cloudtop properties for optically thick clouds. Here, these BTs are converted to a grid with a spatial resolution of $0.25^{\circ}$ lat. $\times 0.25^{\circ}$ long. to agree with the resolution with the TMPA. To examine the large-scale circulations, the six- hourly zonal and meridional winds, temperatures, and rainfall rates are obtained from the National Centers for Environmental Prediction/National Center for Atmospheric Research (NCEP/NCAR) reanalysis (Kalnay et al. 1996) that has a horizontal resolution of $2.5^{\circ}$ lat. $\times 2.5^{\circ}$ long., on 17 pressure levels in the vertical.

The large-scale, low-level zonal winds averaged over the South China Sea during 1999-2008 is used to isolate periods of enhanced low-level westerlies as an indication of ISO variability. A particularly well-defined WWB of the ISO is selected because the low-level westerly winds appeared closely related to well-developed convective cloud clusters over the South China Sea (Nakazawa 2006). Time-series of $850 \mathrm{hPa}$ zonal winds (Fig. 1a) indicates easterly winds in early mid June change to strong ( $\geq 6 \mathrm{~m} \mathrm{~s}^{-1}$ ) westerly winds in mid-to-late June (Fig. 1a). This strong WWB is hypothesized to increase moisture transport into the South China Sea and contribute to the domain-mean daily TMPA rainfall increase to as much as $30 \mathrm{~mm} \mathrm{day}^{-1}$ in mid-late June (Fig. 1b). It is noted that heavy rainfall during 28-30 June was influenced by a tropical cyclone. Thus, an 11-day period 17-27 June 2004 is selected as a strong westerly ISO for investigation in this study.

To diagnose the local circulations associated with the diurnal variation of rainfall, simulations of the atmospheric fields are made using the fifth-generation Pennsylvania State University-National Center Atmospheric Research Mesoscale Model (PSU-MM5). Domain 1 covers South Asia with a 90-km horizontal grid mesh and Domain 2 covers the South China Sea and the Philippines with a
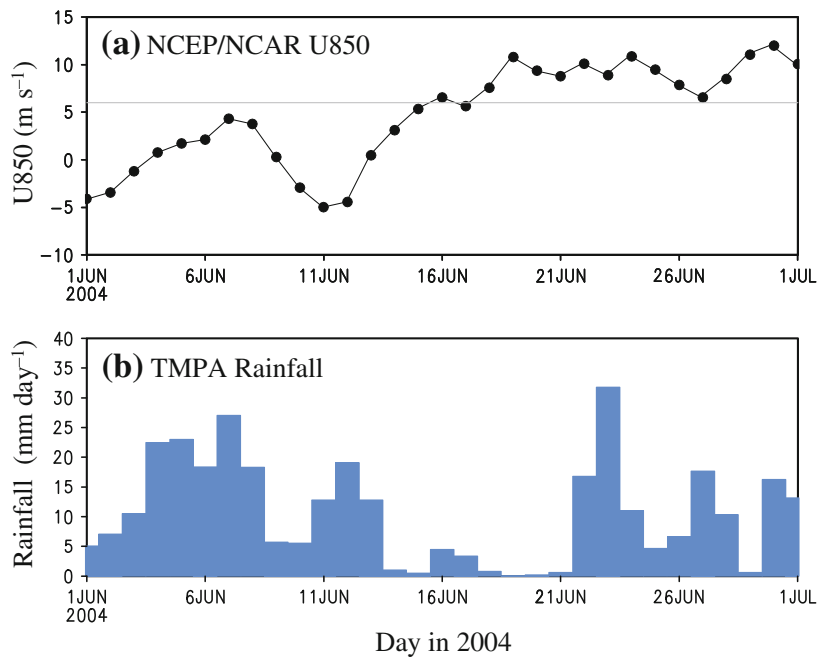

Fig. 1 Time series of a daily-averaged $850 \mathrm{hPa}$ zonal winds $\left(\mathrm{m} \mathrm{s}^{-1}\right)$ from NCEP/NCAR reanalysis and $\mathbf{b}$ rainfall $\left(\mathrm{mm} \mathrm{day}^{-1}\right)$ from Tropical Rainfall Measuring Mission Multi-satellite Precipitation Analysis (TMPA) averaged over South China Sea $\left(110^{\circ}-120^{\circ} \mathrm{E}, 10^{\circ}-\right.$ $20^{\circ} \mathrm{N}$ ) during June 2004 
30-km grid (Table 1; Fig. 2), which is comparable to that of TMPA rainfall and GEOS TB. Each domain has 23 vertical layers in the troposphere below $100 \mathrm{hPa}$, and the outer domain provides lateral boundary values for the inner grids via one-way nesting. Topography from the United States Geological Survey Earth Resources Observing System 9-km dataset (Loveland et al. 1995) for Domain 2 is shown in Fig. 2. Note that northern Philippines (Luzon) is quite mountainous, and the western coast of Luzon lies along $120^{\circ} \mathrm{E}$. The planetary boundary layer model is from the Medium-Range Forecast model of the NCEP (Hong

Table 1 Explanation of the current model runs

\begin{tabular}{ll}
\hline Characteristics & Current setting \\
\hline $\begin{array}{l}\text { Forecast time } \\
\text { Map projection }\end{array}$ & $\begin{array}{l}\text { Mercator } \\
\text { Terrain and land use } \\
\text { input }\end{array}$ \\
$\begin{array}{l}\text { USGS } 30 \text { min }(\sim 9 \mathrm{~km}) \text { global } \\
\text { terrain and land-use }\end{array}$ \\
PBL scheme & Mixed phase \\
Cumulus & MRF \\
parameterization & Kain/Fritsch \\
Surface landscape & \\
Initial data & USGS EROS 1 km \\
FDDA & NCEP/NCAR reanalysis \\
& Grid nudging using the horizontal \\
& wind fields from the NCEP/NCAR \\
& reanalysis data (Nudging coefficient \\
& $\left.2.5 \times 10^{-4}\right)$ \\
\hline
\end{tabular}
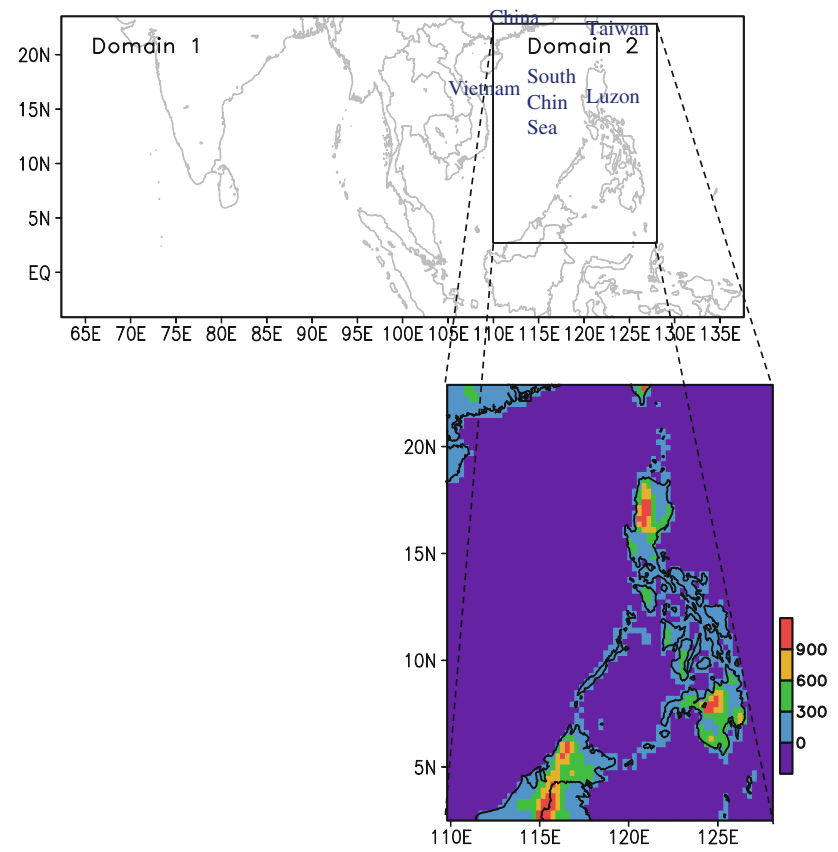

Fig. 2 Model Domains 1 and 2, and the terrain elevation (m) in Domain 2 and Pan 1996), and the explicit mixed-phase moisture scheme is Reisner 1. The Kain and Fritsch (1992) convective parameterization scheme is applied. Although other cloud parameterizations were tested, the Kain-Fritsch scheme was found to be the best in simulating the diurnal variation of rainfall over the target region.

The regional model is integrated for the 16 days from 15 to 30 June 2004 with the initial fields from the NCEP/ NCAR reanalysis for the outer domain and a linear interpolation to the points on the inner domain. A grid-nudging FDDA with the full-physics model incorporated grid-point values from the six-hourly NCEP/NCAR reanalysis, so the model equations assure a consistent large-scale diurnal variation with the reanalysis data (more details are given in the Appendix).

Deep clouds cover a wide area of the South China Sea during the active WWB phase, and a diurnal change of surface temperature over the ocean is considered not to be significant compared to the temperature changes over land. It is thus assumed that the sea surface temperature (SST) cycle is not important to induce the diurnal variation of rainfall over the South China Sea in the vicinity of the Philippines. The current simulation without considering a diurnal SST cycle reasonably represents the diurnal variation of rainfall that is similar with the satellite observation (see later Fig. 5a), which will further support this interpretation.

Two MM5 simulations have been made: one is a control run in which the solar zenith angle simulates the diurnal variation, and the second is a sensitivity test without a local diurnal cycle by prescribing the solar zenith angle fixed at 07 LT over the Philippines. Since the control simulation is successful in replicating the observed diurnal variation of coastal rainfall, the first run, referred as CNTRL hereafter, will be used to diagnose the atmospheric forcing responsible for that variation. The second MM5 sensitivity test, which is referred as the NO_LOCAL experiment, will be used to demonstrate the critical role of the local diurnal circulation (e.g., land-sea breeze) on the upstream coastal sea diurnal rainfall maximum.

\section{Observed daily mean features}

This section examines the daily mean distributions of TMPA rainfall (Fig. 3a) and GOES-9 infrared BT prior to investigating its diurnal variability. For single-layer high clouds with thick optical depths $(\geq 2)$, cloud-top heights are generally above $300 \mathrm{hPa}$, which corresponds to infrared BT values <245 K (Choi and Ho 2006). The domainmean values of TMPA rainfall and infrared BT are $10.2 \mathrm{~mm} \mathrm{day}^{-1}$ and $256 \mathrm{~K}$, respectively. The areas with rainfall exceeding $8 \mathrm{~mm} \mathrm{day}{ }^{-1}$ are widely distributed over the South China Sea and are roughly consistent with low 
(a) TMPA rainfall \& GOES-9 IR BT

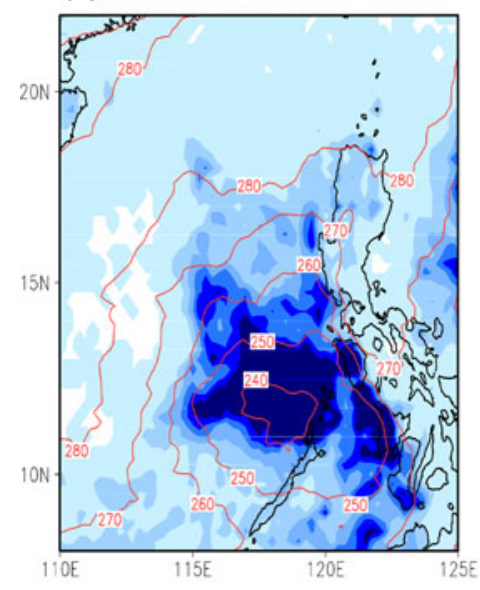

(b) NCEP/NCAR rainfall \& wind at $850 \mathrm{hPa}$

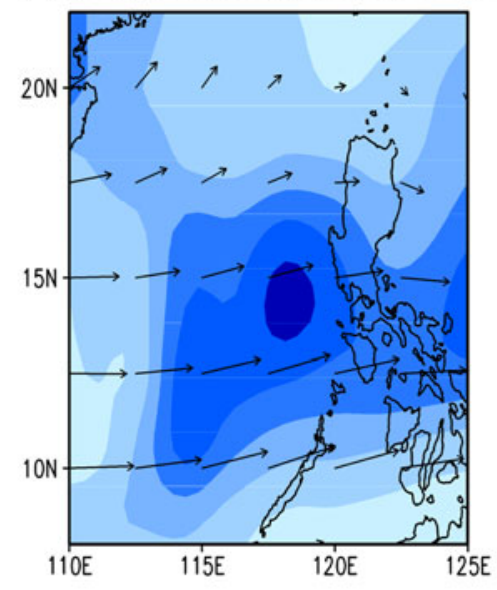

$\overrightarrow{8}$ (c) MM5 rainfall \& wind at $850 \mathrm{hPa}$

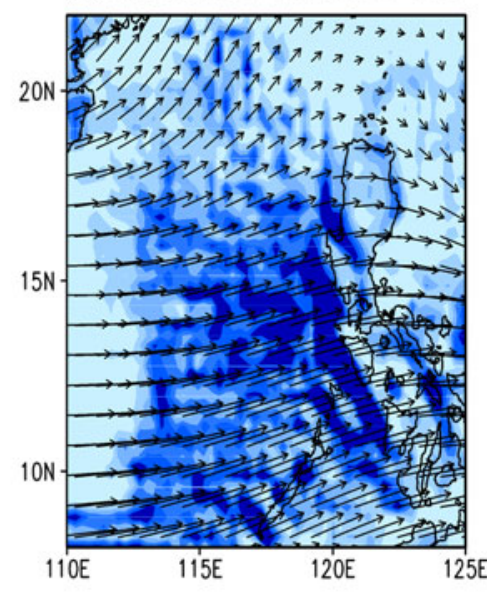

$\overrightarrow{8}$

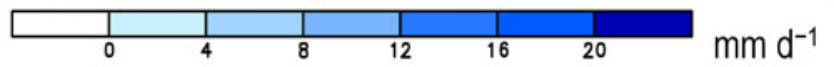

Fig. 3 Distributions averaged for 17-27 June 2004 of a daily mean rainfall from TMPA (shaded, $\mathrm{mm} \mathrm{day}^{-1}$ ) with infrared brightness temperature (contour, K) from the Geostationary Operational

BTs $(<260 \mathrm{~K})$. Interestingly, the BT values of $260 \mathrm{~K}$ and the rainfall values of $12 \mathrm{~mm} \mathrm{day}^{-1}$ in Fig. $3 \mathrm{~b}$ are almost parallel to the coastline of Luzon, so that heavier rainfalls are occurring off the west coast relative to the rainfall over the Philippines. The land-sea difference in rainfall was also found in a previous study by Ho et al. (2008).

Such widespread heavy rainfall should be related with the large-scale circulation during this active ISO period. Large-scale WWBs over the South China Sea are resolved in the NCEP/NCAR reanalysis field (Fig. 3b). In the MM5 CNTRL simulation (Fig. 3c), general features of the circulation are well captured because the grid nudging leads to a similarity with the large-scale wind fields. However, the model winds in the inner domain may differ where the winds are determined by the model physics and dynamics.

The TMPA (Fig. 3a), NCEP/NCAR (Fig. 3b), and the CNTRL experiment (Fig. 3c) have similar distributions of heavy rainfall over the South China Sea, with a maximum between $10^{\circ}$ and $20^{\circ} \mathrm{N}$ off the west coast of Luzon. The domain-mean daily rainfall is also comparable with $6.85 \mathrm{~mm} \mathrm{day}^{-1}$ in TMPA, $6.9 \mathrm{~mm} \mathrm{day}^{-1}$ in NCEP/ NCAR, and $5.5 \mathrm{~mm} \mathrm{day}^{-1}$ in MM5. While the land-sea rainfall distribution is simulated in the MM5 run (Fig. 3a vs. Fig. 3c), it is not depicted well in the relatively coarseresolution NCEP/NCAR reanalysis (Fig. 3a vs. Fig. 3b). These different distributions of rainfall across the Philippines coast have important implications for the land-sea breeze, and may be affected by the diurnal variations of rainfall as well. Whereas the MM5 CNTRL simulates the scattered convective cells somewhat similar to the TMPA,
Environmental Satellite (GOES)-9, and rainfall and winds at $850 \mathrm{hPa}$ from b NCEP/NCAR reanalysis and c MM5 CNTRL experiment

the NCEP/NCAR reanalysis does not resolve these small convective cells.

\section{Observations of the diurnal variations in rainfall and cloud-top temperatures}

Diurnal variations in TMPA rainfall (Fig. 4a) and GOES-9 infrared BT (Fig. 4b) averaged from $10^{\circ}$ to $20^{\circ} \mathrm{N}$ are calculated as deviations from the daily mean (Fig. 3). Since afternoon surface heating and a rainfall peak over coastal land are considered to have important roles in inducing rainfall over the eastern South China Sea the following morning, the ordinate in the displays of diurnal variations of rainfall and atmospheric variables starts from noon on the previous day. Whereas the GOES-9 BTs are available each hour, the TMPA values are only available each $3 \mathrm{~h}$. Over land $\left(120^{\circ}-123^{\circ} \mathrm{E}\right)$, the TMPA rainfall maximum $\left(\geq 0.2 \mathrm{~mm} \mathrm{~h}^{-1}\right.$; Fig. 4a) occurs during the afternoon (15-21 LT). However, the rainfall maximum off the west coast $\left(117^{\circ}-120^{\circ} \mathrm{E}\right)$ occurs from 06 to $14 \mathrm{LT}$. In particular, rainfall just off the coast commences in early morning (03 LT) reaches a maximum farther offshore at $12 \mathrm{LT}$, then decreases later in the afternoon. This offshore diurnal maximum of rainfall is the focus of this study.

In the GOES-9 infrared BT (Fig. 4b), decreases in the infrared BT values $(-4 \mathrm{~K})$ relative to the daily mean ( $\sim 255 \mathrm{~K}$ for coastal sea) are found at 15-23 LT over Luzon, and the weaker BT decreases $(-1 \mathrm{~K})$ appear at 03-18 LT off the coast. Whereas the morning BT decrease 
Fig. 4 Diurnal anomalies (LTdaily mean) averaged from $10^{\circ}$ to $20^{\circ} \mathrm{N}$ of a rainfall $\left(\mathrm{mm} \mathrm{h}^{-1}\right)$ from TMPA and $\mathbf{b}$ infrared brightness temperature $(\mathrm{K})$ from GOES-9 for 17-27 June 2004 (a) TMPA rainfall

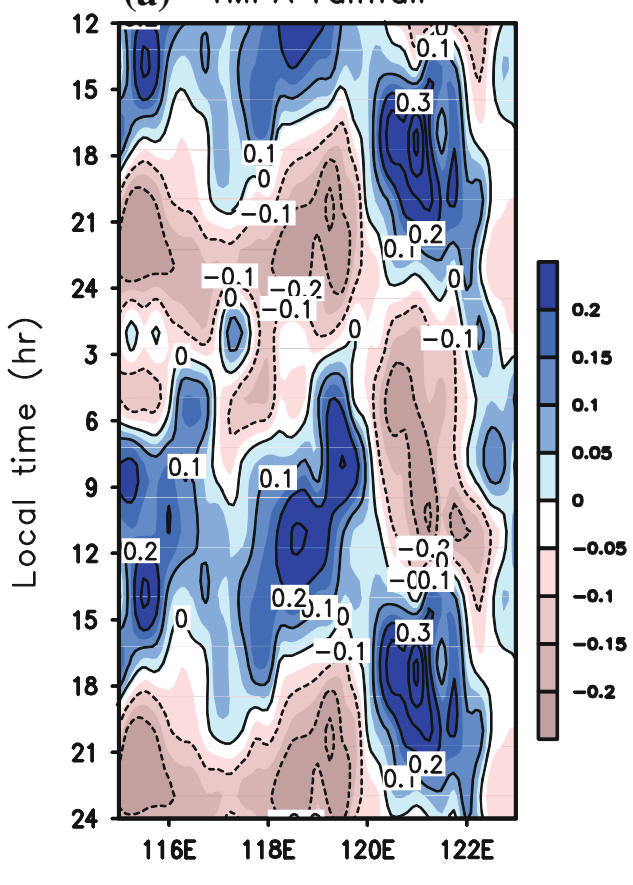

(b) GOES-9 IR BT

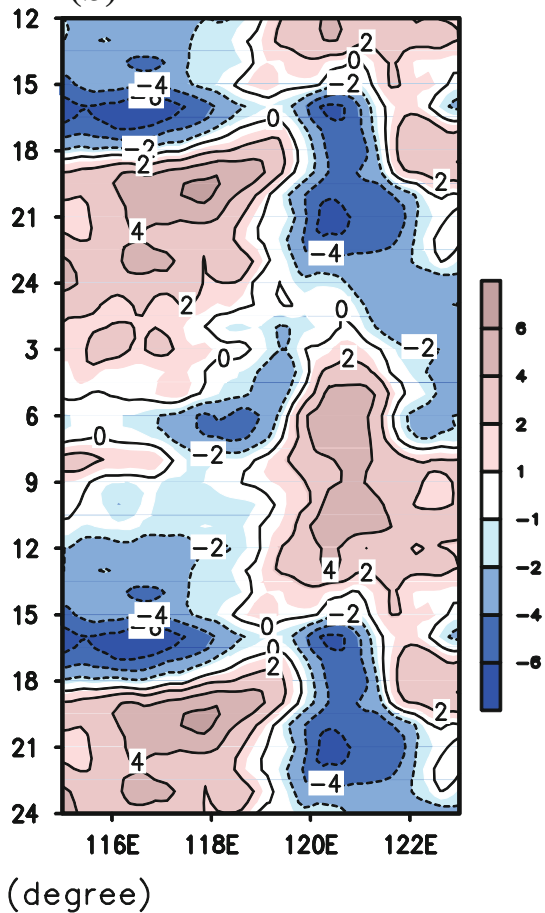

commences over the coastal sea, this area of minimum BT spreads westward over the open sea until $18 \mathrm{LT}$. The duration, timing, and offshore spreading tendency are similar between positive anomalous rainfall $\left(>0 \mathrm{~mm} \mathrm{~h}^{-1}\right)$ and negative anomalous infrared BT $(<0 \mathrm{~K})$. However, the rainfall peak of $0.4 \mathrm{~mm} \mathrm{~h}^{-1}$ occurs around $12 \mathrm{LT}$, and the minimum infrared BT values of $-4 \mathrm{~K}$ are found at 06 and 17 LT. That is, the largest rainfall does not occur at the time of minimum infrared BT. The morning rainfall peak and the afternoon minimum of infrared BT off the coast of Philippines are general diurnal features during the ISO WWBs from the long-term analyses (Ho et al. 2008; Chen and Takahashi 1995) .

It is proposed that a certain type of convective system leads to the rainfall and infrared BT variabilities off the coast of the Philippines. During most days, the size of the system (defined as the areas with IR BT $<208 \mathrm{~K}$ ) during the mature phase exceeds $200-300 \mathrm{~km}$ in diameter, which implies that a well-organized mesoscale convective system (MCS, as in Houze 2004) is a major contributor to the diurnal variation of rainfall over the South China Sea. This MCS has deep convective cells on the leading edge and stratiform rain from an extensive anvil region. Because the satellite microwave and infrared sensors respond differently to rainfall regions and cloud-top temperatures, the diurnal rainfall maximum and the infrared minimum are often not temporally consistent (Yamamoto et al. 2008). That is, the microwave rain retrieval directly detects rain particles and thus reveals the diurnal timing and location of the rainfall, and especially the convective rain region with the larger rain rate. In contrast, an infrared cloud-top temperature minimum may occur during the mature and decaying stages of the MCS (stratiform rain and anvil cloud) as well as during the developing stage (convective rain region) (Yamamoto et al. 2008).

Some insights as to the morphology and life cycle of the cloud system that forms over the South China Sea are assumed from the differences in the TMPA rainfall maximum and the GOES IR minimum in Fig. 4. Notice that the diurnal rainfall maximum occurs in the morning (Fig. 4a), and the IR BT zero contours tend to expand westward in time until the afternoon (Fig. 4b). The cloud system contributing to the diurnal variation of rainfall over the South China Sea is considered to have a development phase initiated off the west coast of Philippines during the morning, which produces intense rainfall and results in a diurnal maximum of rainfall, and then a gradual decay phase occurs as the cloud shield area generated by the convective updraft region drifts westward over the open ocean until the afternoon.

The westward drift of the cloud shield is associated with the large-scale background flows in the middle and upper troposphere. The area-averaged zonal winds from the NCEP/NCAR reanalysis data are $8.73,0.82$, and $-6.22 \mathrm{~m} \mathrm{~s}^{-1}$ at 850,500 , and $200 \mathrm{hPa}$, respectively, which results in an average vertical wind shear $(850-200 \mathrm{hPa})$ of 
$15 \mathrm{~m} \mathrm{~s}^{-1}$. These upper-level easterlies and strong easterly vertical wind shear wind thus contribute to the westward extension of the cloud shield toward the open ocean.

During the decay stage, new convective cells may form on the upstream side of the system as the low-level, moist westerly flow enters the cloud system (Mori et al. 2004). Evidence of new convective cells forming on the western edge of convective system during this WWB period was provided by the cross-sectional distribution of latent heating rate and rain type classification from the TRMM PR Spectral Latent Heating data (Shige et al. 2004) (not shown). Similar distributions of rain and temperature from the numerical model simulations will be presented later.

\section{Model simulation of the diurnal variations in rainfall and circulations}

\subsection{Rainfall and convective updraft}

A primary objective of this research is to understand why the diurnal rainfall maximum over the coastal sea off the Philippines occurs during the morning due to multi-scale interaction with the local diurnal maximum over the Philippines in the previous afternoon. The first step is to demonstrate the model-simulated diurnal rainfall variation reasonably corresponds to the observed diurnal variation. The diurnal maxima of rainfall (Fig. 5a) and 500-hPa vertical velocity (Fig. 5b) on Domain 2 in the MM5 CNTRL experiment occur during the afternoon and evening over the land $\left(120^{\circ}-\right.$ $123^{\circ} \mathrm{E}$ ) and in the early morning over the South China Sea $\left(117^{\circ}-120^{\circ} \mathrm{E}\right)$. Over the sea, the simulated rainfall increases from $03 \mathrm{LT}$ to maxima $>0.1 \mathrm{~mm} \mathrm{~h}^{-1}$ between 06 and $10 \mathrm{LT}$, and then decays during the afternoon (Fig. 5a). The simulated diurnal rainfall maxima over both the sea and land tend to be slightly earlier than that of TMPA (Fig. 5a vs. Fig. 4a). Since the model simulation reasonably well captures the main features of the diurnal rainfall variations in Fig. 4a, these MM5 simulated dynamics and thermodynamics will be used in a diagnostic study of the diurnal rainfall mechanism.

As indicated in Sect. 4, the convective system develops over the sea early in the life cycle in the morning and then is followed by an upscale growth and spreading of the cloud shield (lighter rainfall) on a time scale of $2-4 \mathrm{~h}$ or longer. This strong convective precipitation early in the life cycle is consistent with convective updraft near $116^{\circ} \mathrm{E}$ simulated during the early morning (Fig. 5b). During the afternoon, the simulated vertical motion at $500 \mathrm{hPa}$ is downward even though small rain rates are simulated during 15-18 LT. The decrease in updrafts during the afternoon (Fig. 5b) further supports that the convective system was decaying during the afternoon, but the continued afternoon rainfall can be linked to the morning convective system. Thus, the simulated diurnal variation of the vertical velocity is more consistent with the convective phase of observed life cycle than with later spread of the decaying cloud shield.
Fig. 5 Diurnal anomalies of a rainfall $\left(\mathrm{mm} \mathrm{h}^{-1}\right)$ and $\mathbf{b} 500$ $\mathrm{hPa}$ vertical motion $\left(\mathrm{Pa} \mathrm{s}^{-1}\right)$ from MM5 simulation on Domain 2 averaged from $10^{\circ}$ to $20^{\circ} \mathrm{N}$ for $17-27$ June 2004 (a) Rain

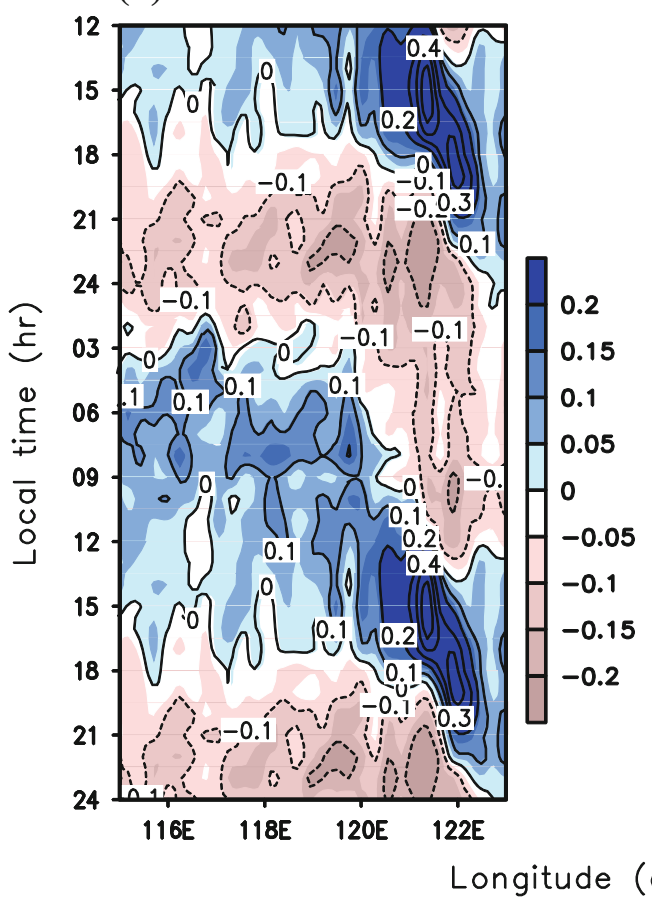

(b) $500-\mathrm{hPa}$ vertical velocty

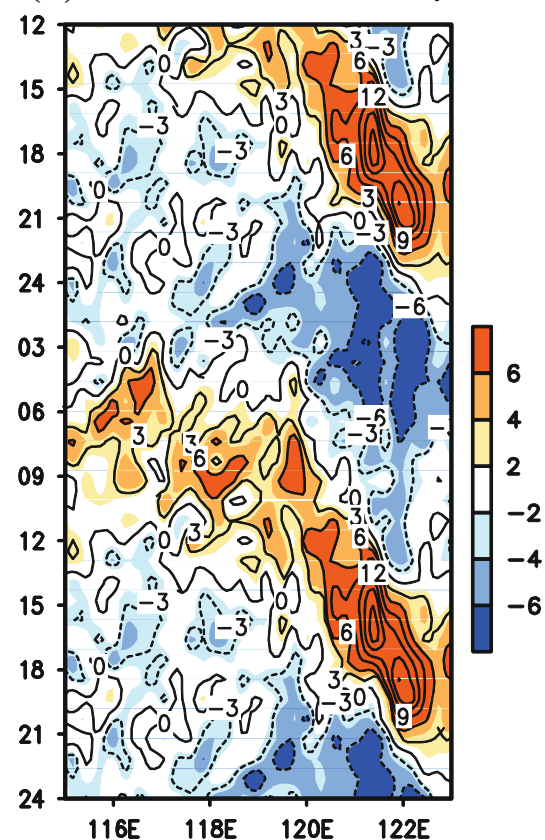


5.2 Low-level convergence influence on the convective process

Over Luzon (east of $120^{\circ} \mathrm{E}$ ), a strong $925-\mathrm{hPa}$ convergence $\left(>7 \times 10^{-6} \mathrm{~s}^{-1}\right)$ designated as $\mathrm{C} 1$ appears around $12 \mathrm{LT}$, and it later occurs on the eastern slope of the mountains around $18 \mathrm{LT}$. Another low-level local convergence off the west coast of Philippines between $117^{\circ}$ and $120^{\circ} \mathrm{E}$ is designated as $\mathrm{C} 2$, which commences at $05 \mathrm{LT}$, reaches maximum values of $0.6 \times 10^{-6} \mathrm{~s}^{-1}$ at $10 \mathrm{LT}$, decays after $14 \mathrm{LT}$, and finally disappears at $18 \mathrm{LT}$ (Fig. 6a). These diurnal variations of low-level convergence are quite similar to those of rainfall (Fig. 5a), because in the unstable atmosphere over the South China Sea air parcels that are lifted from the boundary layer via the increased convergence would quickly become buoyant. The purpose of this subsection is to understand of evolution of $\mathrm{C} 1$ and $\mathrm{C} 2$ (Fig. 6a) that lead to the diurnal rainfall maxima (Fig. 5a).

In this simulation of a strong WWB period, the prevailing westerly winds over the sea $\left(\sim 115^{\circ} \mathrm{E}\right)$ also have a diurnal cycle with a minimum $\left(-1.0 \mathrm{~m} \mathrm{~s}^{-1}\right)$ between 20 and $05 \mathrm{LT}$ and a maximum $\left(2.1 \mathrm{~m} \mathrm{~s}^{-1}\right)$ during 06-18 LT. This diurnal perturbation on the monsoon westerlies rotates clockwise in time; that is, the perturbations are approximately easterly, southerly, westerly, and northerly at 00 , 06, 12, and $18 \mathrm{LT}$, respectively. This striking variation in low-level wind will later (Fig. $10 \mathrm{~g}-\mathrm{j}$ ) be shown to occur over the broad area of the South China Sea. Consequently, this is a large-scale perturbation of the prevailing monsoon westerlies.

A more localized diurnal variation of low-level wind is associated with the afternoon convergence $\mathrm{C} 1$ in vicinity of the Philippines (Fig. 6b). A local diurnal circulation in the afternoon is onshore, the enhanced large-scale westerly flow crosses the coast and a maximum low-level convergence occurs over Luzon in the afternoon. When the diurnally varying winds on the coast $\left(120^{\circ} \mathrm{E}\right)$ and the open sea $\left(\sim 117^{\circ} \mathrm{E}\right)$ are in different phases during the early morning, the low-level convergence will be increased offshore. As shown in Fig. 6b, the wind variations (westerlies vs. weak easterlies changing to southerlies) begin to occur between the open sea and the coastline around $05 \mathrm{LT}$, and the offshore convergence begins to increase around this time. Later, enhanced large-scale westerlies are simulated over the open sea, while weak easterly anomalous flow remains parallel to the coastline, so the low-level convergence maximum $\mathrm{C} 2$ occurs in the morning around $08 \mathrm{LT}$.

This diurnal variation of low-level convergence offshore is balanced with the vertical velocity that either enhances or suppresses convection and the associated latent heating (or cooling) that can alter atmospheric temperature. Another factor modulating the temperature variability is radiative forcing, and the primary feature in this (a) Convergence

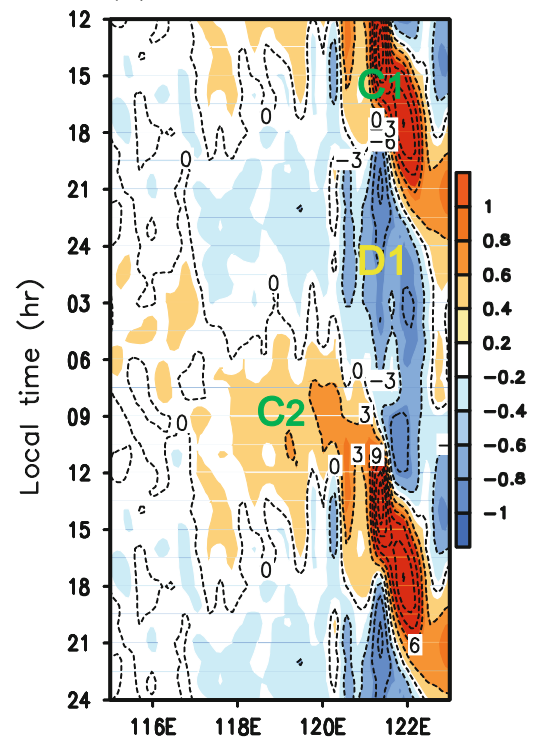

(b) (Zonal) Wind

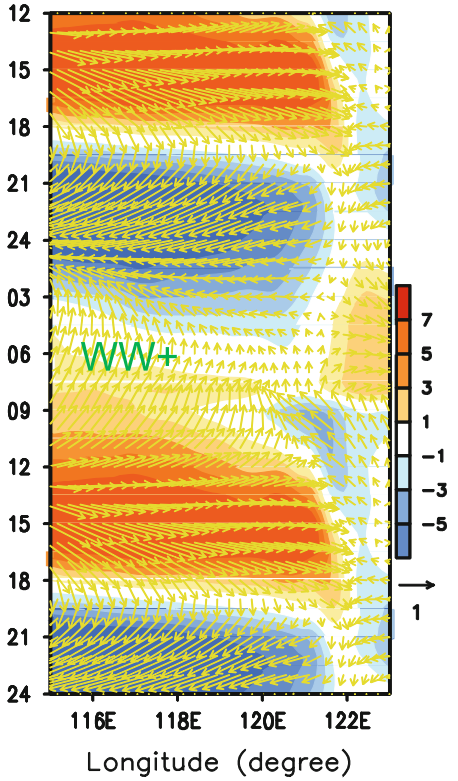

(c) Temperature

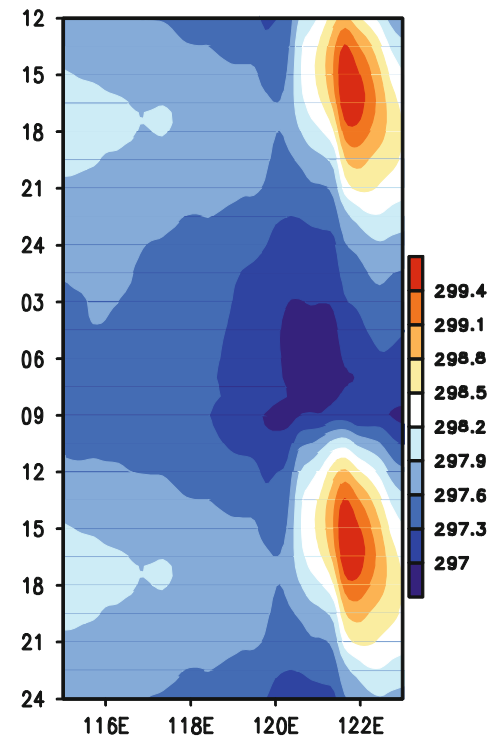

Fig. 6 Diurnal anomalies (LT-daily mean) of a convergence $\left(10^{-6} \mathrm{~s}^{-1}\right.$, color bar on right) and $\mathbf{b}$ zonal wind (shaded, $\mathrm{m} \mathrm{s}^{-1}$ ) and horizontal wind (vector), and diurnal variation of $\mathbf{c}$ atmospheric temperature $(\mathrm{K})$ at $925 \mathrm{hPa}$ from MM5 CNTRL experiment. Two simulated convergence regions that lead the afternoon rainfall peak over Philippines and the morning rainfall peak off the west coast (Fig. 5a) are designated as $C 1$ and $C 2$, and a simulated nighttime anomalous divergence over the Philippines is designated as Dl. Positive diurnal tendency of large-scale westerlies over the open sea is designated as $W W+$ 
temperature variation in the coastal regions is the land-sea differential heating. In the CNTRL, the diurnal variation of low-level temperature (Fig. 6c) over land is larger than over the sea during daytime, but lower from sunset to sunrise. This land-sea differential heating drives local winds in Fig. $6 \mathrm{~b}$ with onshore flow in the afternoon and offshore during the night. Whereas the highest mountain in northern Luzon is around 3,000 $\mathrm{m}$, the maximum terrain elevation in model Domain 2 is about 1,000 m (Fig. 2). This elevated topography enhances the land heating with the maximum temperature on the highest terrain at around 15 LT (Fig. 5c). By contrast, the minimum temperature is to the west of the highest terrain. This enhanced differential heating due to elevated terrain over Luzon is consistent with the localized diurnal variation of onshore and offshore winds along the west coast (Fig. 6b). Notice the region of negative $925 \mathrm{hPa}$ temperature anomalies near the west coast of Philippines that have maximum values between 03 and 09 LT (Fig. 6c). This region of cold air, which extends well offshore with decreasing anomalous values, implies a cold pool that may provide a lifting mechanism with the enhanced westerly winds during the morning.

The vertical structure of local circulation in relation to the elevated terrain over Luzon has a strong diurnal variation (Fig. 7). At 14 LT (Fig. 7a), the simulated local circulation over the Philippines has low-level convergence and mid-to-upper level divergence with strong upward motion above the mountain area. The low-level westerly flow extends some distance offshore over the South China Sea since the strong onshore breeze that is induced by the elevated terrain heating is in phase with the local-scale westerly wind anomaly (Fig. 6b).

At 20 LT (Fig. 7b), the upward motion over the Luzon terrain has weakened. Subsidence offshore has lead to a weak low-level divergence in response to the mid-to-upper level convergence. Consequently, only a weak low-level circulation remains over the east coast of Luzon.

At 02 LT (Fig. 7c), a strong subsidence is simulated over Luzon in conjunction with strong low-level divergence (from 900 to $800 \mathrm{hPa}$ ) and mid-to-upper level convergence (from 600 to $300 \mathrm{hPa}$ ). At this time, the local offshore breeze combines with anomalous easterly winds of the larger-scale diurnal circulation so that the entire South China Sea has anomalous low-level easterlies. Anomalous westerly flow exists at upper levels with subsidence over the eastern South China Sea.

By early morning (05 LT), the low-level divergence circulation D1 above the Luzon terrain is weakened (Fig. 6a), but low-level divergence still maintains a weak offshore flow (Fig. 7d). Meanwhile, the large-scale, low-level anomalous wind is changing from easterlies to westerlies (WW+ in Fig. 6b), which initiates the offshore convergence $\mathrm{C} 2$ (Fig. 6a). By $08 \mathrm{LT}$ (Fig. 7d), a significant region of
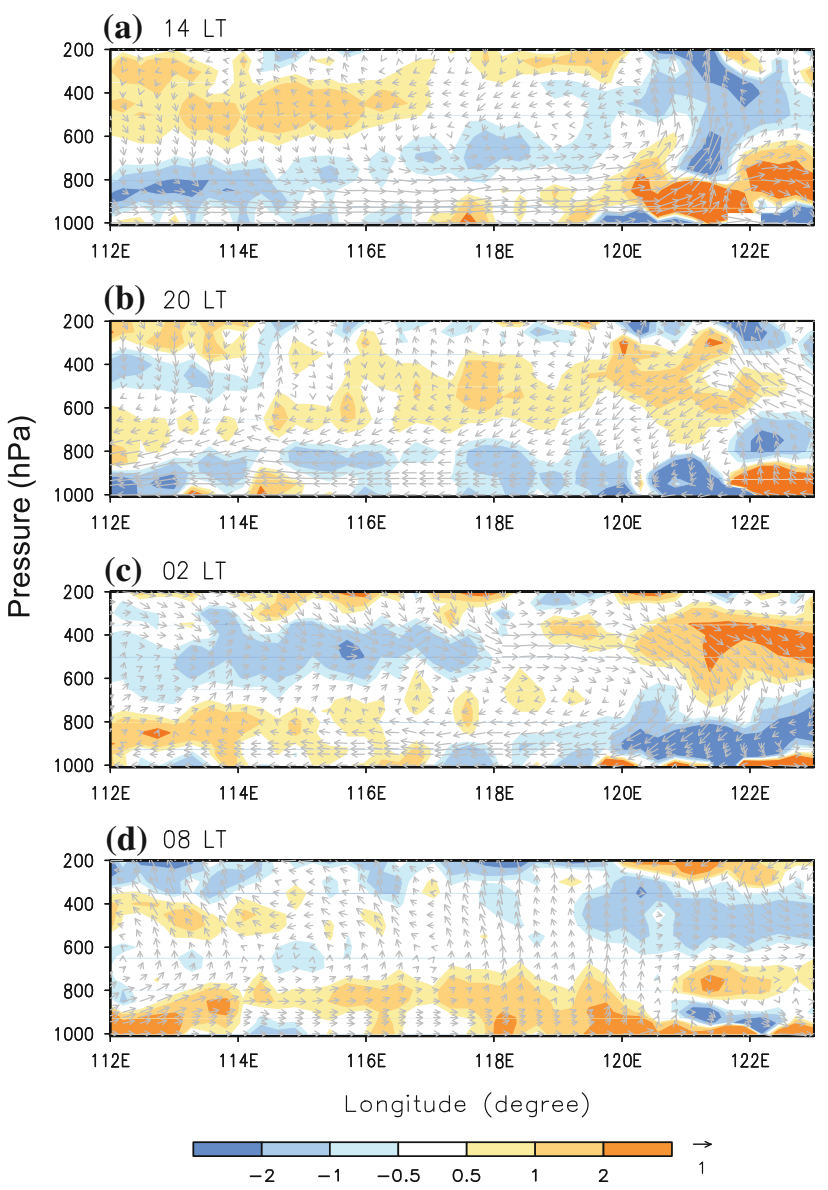

Fig. 7 East-west cross-section of anomalous convergence (shading, $10^{-6} \mathrm{~s}^{-1}$ ), and zonal/vertical winds (vector, $\mathrm{m} \mathrm{s}^{-1}$, magnitude of vertical wind amplified by 100) at: a 14, b 20, c 02, and d 08 LT averaged from $15^{\circ}$ to $17^{\circ} \mathrm{N}$ for $17-27$ June 2004

low-level convergence and ascent is simulated from $118^{\circ} \mathrm{E}$ to the Philippines coast. Consequently, low-level convergence $\mathrm{C} 2$ and upward motion is simulated by increased lowlevel anomalous winds (WW+) over the open sea while the local divergence (D1 in Fig. 6a) is still maintaining offshore flow across the west coast of the Philippines.

In summary, the simulation of diurnal variation of convergence includes two diurnal circulations during this WWB period, one on the local scale and another on the large-scale. Whereas a local-scale diurnal circulation induces $\mathrm{C} 1$, it is the interaction between these two diurnal circulations that induces the offshore low-level convergence $\mathrm{C} 2$, ascent, and rainfall in the morning. If one considers that $\mathrm{C} 2$ is not due to the multi-scale interaction of two diurnal circulations, then one of two hypotheses must be valid:

HY1: C2 arises only from a local diurnal circulation (offshore land breeze) interacting with (diurnally-invariant) large-scale westerlies as in Houze et al. (1981); or HY2: $\mathrm{C} 2$ is due only to the large-scale diurnal circulation. 
In the current simulation, $\mathrm{HY} 1$ fails because $\mathrm{C} 2$ did not have its maximum around 02 LT (diurnal time of maximum offshore land breeze). In the next subsection, it will be demonstrated that the NO_LOCAL experiment does not simulate C2. HY2 also fails because $\mathrm{C} 2$ does not have an afternoon maximum (diurnal time of the maximum largescale westerlies). Accordingly, the failures of these two hypotheses based on Fig. 6 and Fig. 7 indicates that the offshore convergence $\mathrm{C} 2$ is then more likely due to the multi-scale interaction of the two diurnal circulations.

\subsection{Contribution of local diurnal variability on the low-level convergence}

The key result in the previous section is that an interaction between two diurnal circulations of different spatial scales is essential in the formation of a morning rainfall maximum over the eastern South China Sea. This result implies that the absence of the local diurnal circulation over the Philippines would lead to an improper simulation of rainfall maximum. Indeed, some coarse resolution global or regional circulation simulations do not represent the diurnal variations of such local circulations. To illustrate the effect when the local diurnal circulation over the Philippines does not exist, a sensitivity test (NO_LOCAL) is performed in which a fixed solar zenith angle is maintained to remove the local diurnal variability. However, the gridnudging feature for the large-scale diurnal variations superposed on the WWB circulation is maintained over the South China Sea.
Diurnal variations of the $925-\mathrm{hPa}$ convergence and wind vectors from the CNTRL experiment in Fig. 8 are contrasted in Fig. 9 with simulation fields from the NO_LOCAL experiment. Notice the prevailing westerly winds between Vietnam and Luzon are stronger during 14, 17, 08, and $11 \mathrm{LT}$ and are reduced during 20,23, 02, and $05 \mathrm{LT}$ in both experiments, which is consistent with a clockwisevarying large-scale diurnal circulation as mentioned in the Sect. 6. The simulated diurnal variation of local circulation over Philippines in the CNTRL experiment has convergence during daytime (Fig. 8a, b, h) and divergence from midnight to morning over Luzon (Fig. 8c-e), which is consistent with the diurnal variation of convergence over land at longitudes $>120^{\circ} \mathrm{E}$ in Fig. 5b. Notice that $\mathrm{C} 1$ and D1 from Fig. 6 are at 14 LT (Fig. 8a) and 02 LT (Fig. 8e). $\mathrm{C} 1$ is low-level convergence that results from the landsurface heating (Yang and Smith 2006), and typically produces a subsequent rainfall maximum. However, these typical afternoon local circulations do not occur in the NO_LOCAL experiment (Fig. 9a, b) in which the solar zenith angle is fixed at 07 LT time.

In the CNTRL experiment, the early morning low-level convergence $\mathrm{C} 2$ and rainfall maximum over the eastern South China Sea depend on a morning offshore flow (Fig. 8g) that has persisted since the offshore flow maximum near midnight (Fig. 8e). In the NO_LOCAL experiment, such a morning offshore flow is not simulated (Fig. 9g). Rather, an apparent coastal convergence maximum occurs during the afternoon (14 and 17 LT) in the NO_LOCAL experiment (Fig. 9a, b) when the prevailing

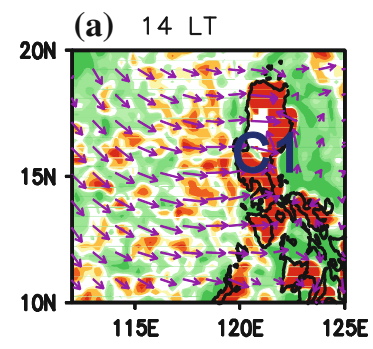

(b) $17 \mathrm{LT}$

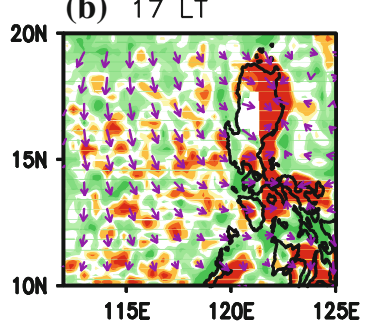

(e) $02 \mathrm{LT}$

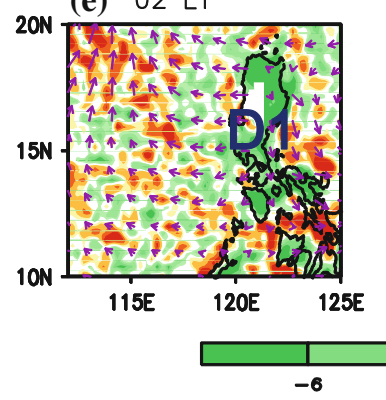

(f) $05 \mathrm{LT}$

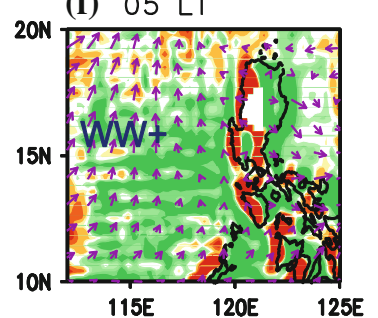

(c) $20 \mathrm{LT}$

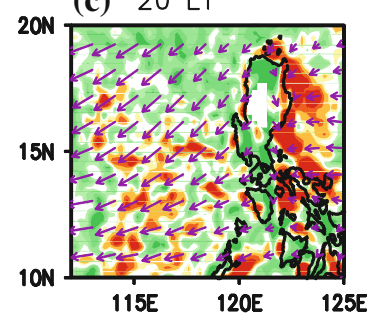

(g) $08 \mathrm{LT}$
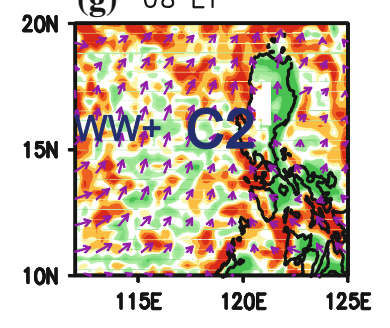

(d) $23 \mathrm{LT}$

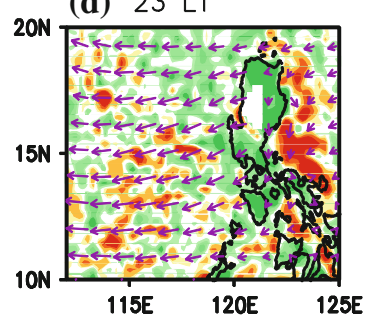

(h) 11 LT

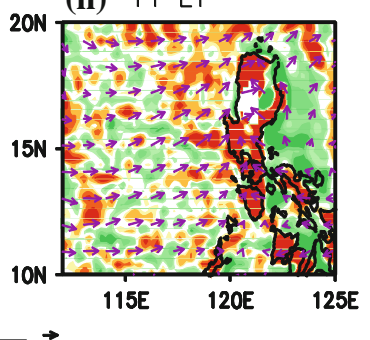

Fig. 8 The horizontal distributions of anomalous convergence (shading, $10^{-6} \mathrm{~s}^{-1}$ ) and wind field (vector, $\mathrm{m} \mathrm{s}^{-1}$ ) every $3 \mathrm{~h}$ from the CNTRL simulation. Red shading indicates the diurnal increase of convergence. $C 1, C 2, D 1$, and $W W+$ in Fig. 6 are also designated in the figure 
(a) 14 LT No C1

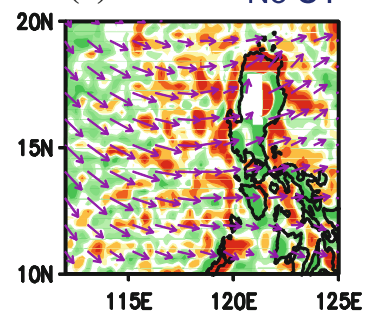

(e) 02 LT No D1

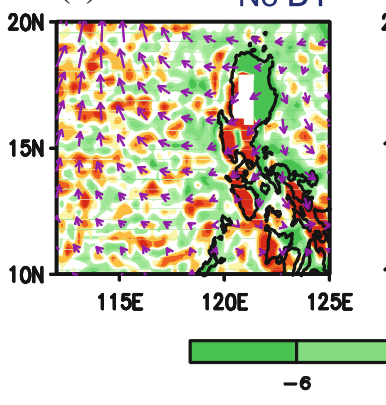

(b) $17 \mathrm{LT}$

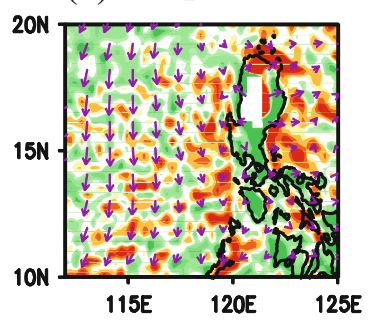

$20 \mathrm{~N}$

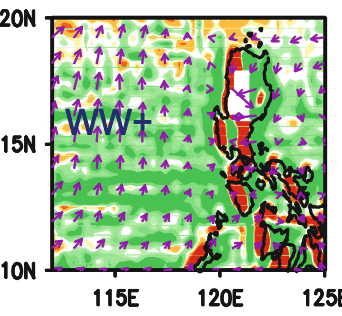

(c) $20 \mathrm{LT}$

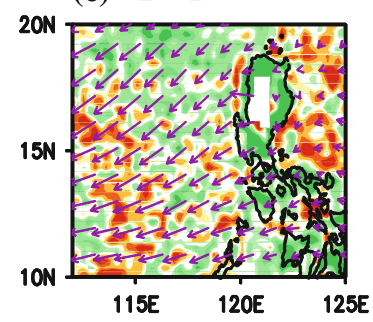

(g) 08 LT No C2 (d) $23 \mathrm{LT}$

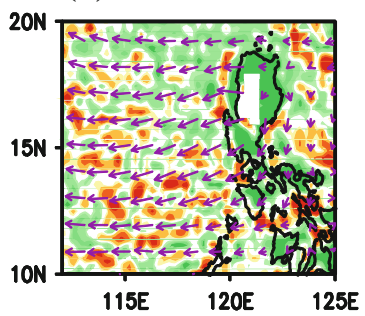

(h) $11 \mathrm{LT}$

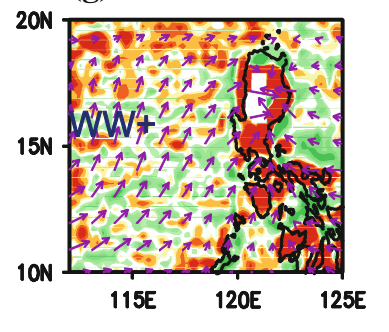

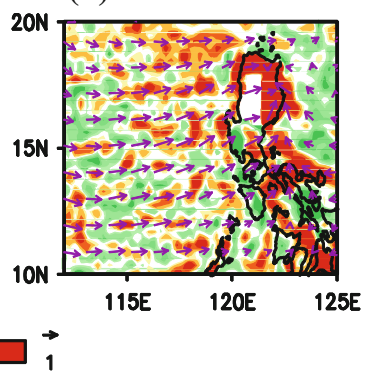

Fig. 9 As in Fig. 8, except for the NO_LOCAL experiment. Low-level convergence C1, D2, and C2 simulated in the CNTRL are not present due to the absence of local diurnal circulation

westerly winds advance toward coast and encounter the mountains near the coast. This evolution is primarily due to the large-scale daily mean circulation, rather than local diurnal circulation as in the CNTRL simulation in which the solar-zenith angle would correspond to 14 LT.

As expected, this sensitivity test in which the local diurnal cycle over the Philippines is suppressed does not lead to an offshore flow in the early morning that then converges with the enhanced monsoon westerlies. Without this interaction between the local diurnal variation and the large-scale circulation diurnal variability, the observed rainfall maximum in the eastern South China Sea is not simulated.

Although the CNTRL experiment in this study revealed the existence of an offshore flow occurring on mesoscale (Fig. 5c), this offshore flow was relatively weak, which may be attributed to the relatively coarse resolution in the numerical model. In particular, the differential cooling between land and sea in this region will be underestimated due to an inadequate resolution of the mountains over Philippines. After sunset, the air above these coastal mountains would undergo stronger radiative cooling than that has been simulated in the CNTRL experiment. In addition, Mahrer and Pielke (1977) examined the relative importance of "land-sea thermal contrast versus mountain effect" and showed the latter is dominant for mountains more than few hundred meters high. In the CNTRL experiment, the near-coast topography of Luzon is underestimated, so the offshore flow driven by the mountain effect will also be underestimated. Another mesoscale effect that may be under-resolved is generation of 'cold pool' from the deep convective systems. In the CNTRL simulation, the diurnal maximum rainfall over the Philippines occurs in afternoon (15 LT), and then the maximum shifts eastward until evening (Fig. 5a). In nature, such an eastward-moving convective system during the afternoon would produce the 'cold pool' behind it. The relatively coarse resolution of the model does not properly treat that evolution. As the previous convection decays, the (latent) cooling due to evaporation and melting of precipitation of the diurnal afternoon convective systems would be expected to form cold pools over the west coast of the Philippines. Thus, it is suggested that inclusion of cold pool dynamics over the Philippines would lead to stronger mesoscale offshore flows interacting with the large-scale diurnal circulation.

\subsection{Origin of large-scale diurnal variability in the low-level convergence}

As indicated in Sect. 5.2, the diurnal variation of the largescale circulation in the MM5 CNTRL has an important contribution to the diurnal rainfall maximum over the eastern South China Sea. The large-scale diurnal variation revealed by Krishnamurti and Kishtawal (2000) has a large-scale, low-level convergent flow over the continent at 12 UTC and divergent flow at 00 UTC. Wang (2006) pointed out that the diurnal anomalous large-scale 
circulation varies clockwise in time. These diurnal features of the large-scale flows are reflected in the six-hourly NCEP/NCAR reanalysis winds during 17-27 June 2004 that are used as the initial and nudged field in the CNTRL simulation.

Daily mean values and diurnal anomalies for the NCEP/ NCAR reanalysis near-surface temperature and vertical velocity, surface rainfall, and $925 \mathrm{hPa}$ winds at $06,12,18$, and 00 UTC are given in Fig. 10. The near-surface temperature and rainfall variations are related to the surface and latent heating, respectively. The daily temperatures are low in the vicinity of the southeastern part of the Tibetan
Plateau owing to its high elevation (Fig. 10a). Even in the daily mean, upslope motion $\left(<-10 \mathrm{~Pa} \mathrm{~s}^{-1}\right)$ exists along the southern slope of the Plateau (Fig. 10f). The daily mean rainfall is higher in subtropical regions than in extratropical regions (Fig. 10a).

At 06 UTC (14 LT over the South China Sea and 11 LT over the Tibetan Plateau), differential surface temperatures between the continent and the surrounding sea are increasing with maximum values over the northern China $\left(30^{\circ}-40^{\circ} \mathrm{N}, 90^{\circ}-120^{\circ} \mathrm{E}\right)$ due to the diurnal maximum of solar heating over this region (Fig. 10b). In addition, larger rainfall is analyzed over the Indochina Peninsula
Fig. 10 Daily means $(\mathbf{a}, \mathbf{f})$ and diurnal anomalies (UTC-daily mean) at $06,12,18$, and 00 UTC $(\mathbf{b}-\mathbf{e}, \mathbf{g}-\mathbf{j})$ from the NCEP/NCAR reanalysis data over a larger area including the Tibetan Plateau during 17-27 June 2004: near-surface temperature (shaded, K, scale at bottom) and rainfall (contour, $\left.\mathrm{m} \mathrm{h}^{-1}\right)$ in left panels, and $925 \mathrm{hPa}$ wind (vector, $\mathrm{m} \mathrm{s}^{-1}$, daily mean scale on right of f and daily anomaly scale on right of $\mathbf{g}$ ) and vertical velocity (shaded, $-\mathrm{Pa} \mathrm{s}^{-1}$, scale at bottom, solid and dotted contours for 10 and $-10 \mathrm{~Pa} \mathrm{~s}^{-1}$ ) in right panels (a)

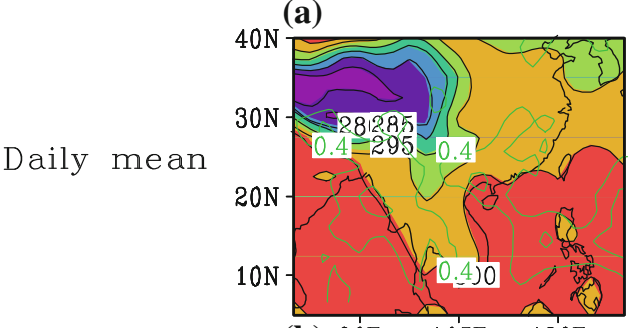

(b) $90 \mathrm{E} \quad 105 \mathrm{E} \quad 120 \mathrm{E}$

06 UTC

$12 \mathrm{UTC}$

$18 \mathrm{UTC}$

00 UTC

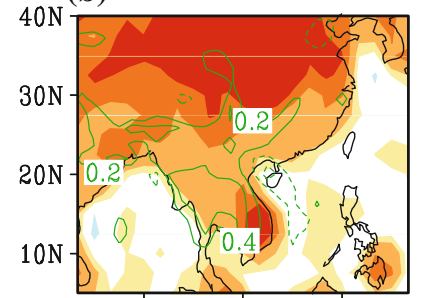

(c) $90 \mathrm{E}$
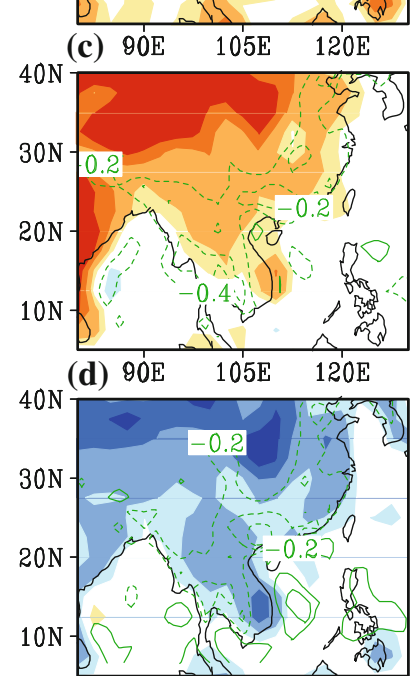

(e) $90 \mathrm{E} \quad 105 \mathrm{E} \quad 120 \mathrm{E}$

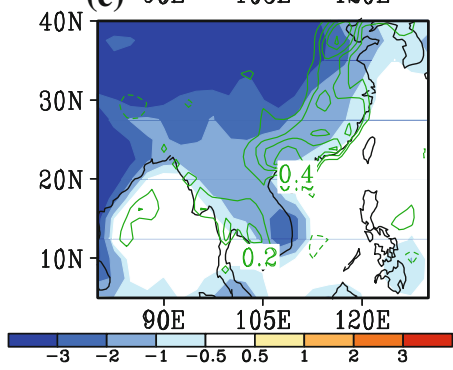

(f)

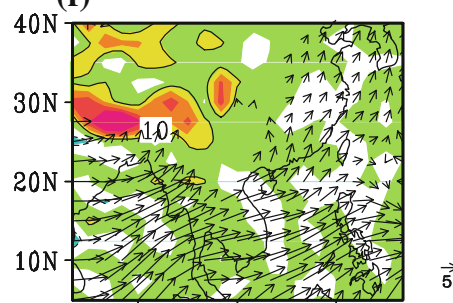

(g) $90 \mathrm{E} \quad 105 \mathrm{E} \quad 120 \mathrm{E}$

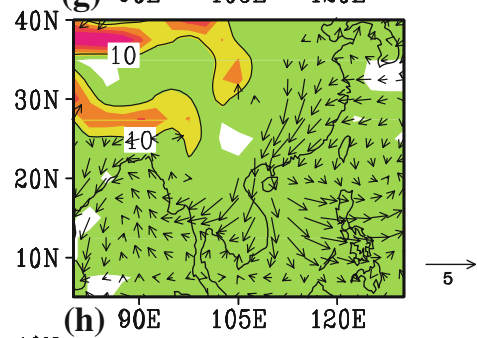

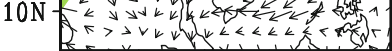
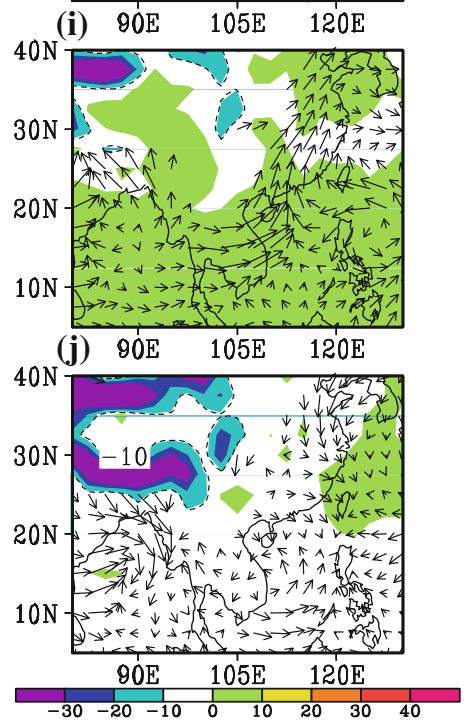
$\left(10^{\circ}-20^{\circ} \mathrm{N}\right)$ than over the South China Sea (especially near $\left.110^{\circ} \mathrm{E}\right)$ or over northern China $\left(30^{\circ}-40^{\circ} \mathrm{N}\right)$ at the same longitude. Since the troposphere over the subtropics is generally conditionally unstable and that over the midlatitudes is less unstable, the convection over the Indochina Peninsula may be triggered earlier than in the northern China region. The direct atmospheric response to diabatic heating is the convergent circulation at low levels, and anomalous equatorward flows are apparent over eastern China that extend to the western South China Sea at 06 UTC (Fig. 10g).

At 12 UTC (20 LT over the South China Sea and 17 LT over the Plateau), the strong surface heating over the high plateau region compared to the surrounding continental land and ocean regions leads to positive temperature anomalies (Fig. 10c), and anomalous ascent along the southern boundary over the Plateau, as well as ascent as far east as $105^{\circ} \mathrm{E}$ (Fig. 10h). Notice that the diurnal circulation over the Plateau is connected to the diurnal variation over the entire East Asian landmass extending to the East China and to the South China Sea, and that the anomalous wind component over the South China Sea now has an easterly component (Fig. 10h) as in Fig. 7b. The differential heating over the East Asian continent, and especially the elevated landmass of the Tibetan Plateau, is thus important in inducing the large-scale diurnal circulation over the South China Sea. Given the 6-h time resolution of the NCEP/ NCAR reanalyses, the differential heating between the Plateau and the surrounding air is larger at 12 UTC than at 06 UTC, which was the time of the diurnal maximum in solar heating over the Philippines.

After sunset, differential cooling between the continent and the surrounding seas occurs, and in the vicinity of the Tibet Plateau such a differential cooling is expected to drive shallow downslope (katabatic) flows. At 18 UTC (02 LT over the South China Sea and 23 LT over the Plateau), negative temperature anomalies are found over the continent with maximum values over East China (Fig. 10d) and anomalous downward motion ( $>10 \mathrm{~Pa} \mathrm{~s}^{-1}$ ) in vicinity of the Plateau. Over the Indochina Peninsula and extending into the western South China Sea, the anomalous wind is reversing again to become westerlies, which corresponds to the beginning of a westerly wind tendency that is designated $\mathrm{WW}+$ in Fig. 6b.

At 00 UTC (08 LT over the South China Sea and 05 LT over the Plateau), large negative temperature anomalies exist over the Plateau and the entire landmass of East and Southeast Asia (Fig. 10e), with the largest anomalous downward motion ( $>30 \mathrm{~Pa} \mathrm{~s}^{-1}$ ) localized along the southern slope of the Plateau (Fig. 10j). The large-scale anomalous circulation response to this cooling is somewhat more regionalized than during the warming period. Specifically, westerly wind anomalies are now occurring over the South China Sea extending to the west coast of the Philippines (Fig. 10j), which corresponds to the reversal from low-level easterlies in Fig. 7c to westerlies at $08 \mathrm{LT}$ in Fig. 7d. In combination with the offshore wind flow from the Philippines, this leads to the upstream low-level convergence C2 over the eastern South China Sea in Fig. 6a. Thus, it is the large-scale response to the differential heating and cooling over the Asian continent and the Tibetan Plateau that leads to a westerly wind component of the large-scale circulation over the South China Sea that is out of phase with the local diurnal circulation over the Philippines in the early morning.

In both the CNTRL and the NO_LOCAL simulations, this large-scale diurnal circulation in response to the largescale differential heating and cooling and the distribution of latent heating is the forcing on Domain 1. Specifically, the reversals of the low-level winds over the central South China Sea in Fig. 7 are a representation of the large-scale diurnally varying circulations in Fig. 10. For the CNTRL simulation in Figs. 7 and 8, the interaction with the local diurnal circulation induced by the Philippines leads to the low-level convergence $\mathrm{C} 2$ region upstream of the Philippines. Without the local diurnal variation (NO_LOCAL in Fig. 9), this large-scale forcing does not lead to an upstream convergence region in the morning (Fig. 9g).

\section{Summary and conclusion}

The objective of this research has been to understand the mechanisms that lead to an observed convection and rainfall maximum in the early morning off the west coast of the Philippines during the WWBs. The CNTRL numerical experiment in Sect. 5.2 indicates that this rainfall mechanism arises from an interaction between the local diurnal circulation over the Philippines and a large-scale diurnal circulation over the South China Sea. A sensitivity test (Sect. 5.3) in which the solar-zenith angle is fixed to remove the local diurnal variations over the Philippines does indicate that an interaction of that local diurnal circulation with the diurnally varying large-scale circulation is essential for simulating the timing and location of the offshore rainfall maximum. Diagnosis of the diurnal variation of the large-scale circulations in the NCEP/NCAR reanalysis during the WWB studied here provide evidence (Sect. 5.4) that the evolution over east Asia continent with Tibet Plateau is consistent with the simulated low-level convergence over the eastern South China Sea.

A conceptual model of the diurnal evolution of the atmospheric circulations and rainfall during afternoon, evening, night, and morning (Philippines local time) is shown in Fig. 11a-d. The two primary diurnal circulations over the South China Sea are indicated as anomalies of the 
(a) Afternoon ( 14 LT/06 UTC)

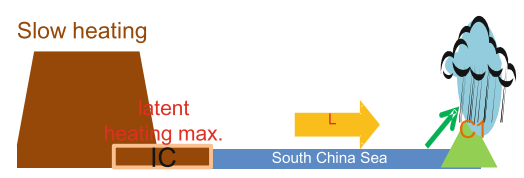

(b) Evening ( 20 LT/12UTC)

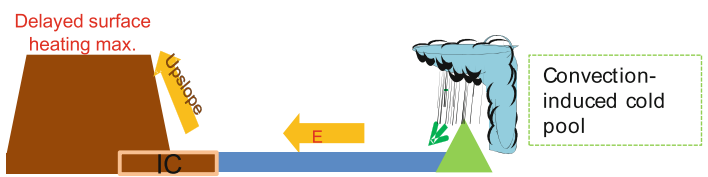

(c) Night ( 02 LT/18UTC)

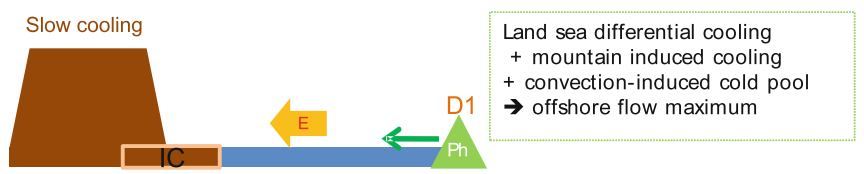

(d) Morning ( 08 LT/00UTC)

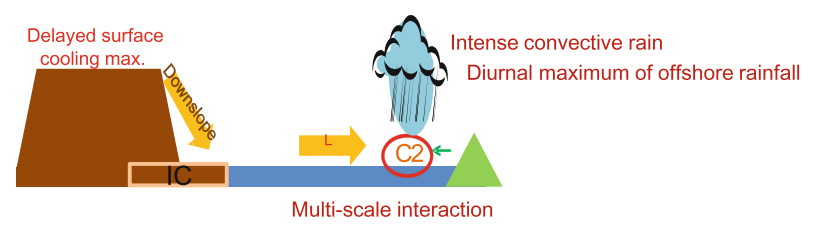

Fig. 11 Schematic diagrams of the multi-scale interaction of two diurnal circulations leading to morning diurnal maximum of rainfall over the eastern South China Sea. The two primary diurnal circulations over the South China Sea are indicated as anomalies of zonal winds: (1) large-scale diurnal variation of WWBs (yellow thick arrows) associated with Asia continent (indicated as brown) including the Indochina Peninsula (IC) and Tibetan Plateau, and (2) mesoscale diurnal circulation (green thin arrows) interacting with Philippines (indicated as light green triangle). The low-level convergence and upstream coastal convection are represented as ' $C 2$ ' and 'image of rainy cloud' in panel. The arrows $L$ and $E$ indicate anomalies of largescale zonal wind zonal winds: (1) the diurnally varying large-scale westerlies during a WWB (yellow thick arrows) that are associated with Asian continent; and (2) local mesoscale diurnal circulation (green thin arrows) associated with the Philippines. The diurnal evolutions of these two circulations leading to a rainfall maximum over the eastern South China Sea during the morning are summarized based on this research:

Afternoon (Fig. 11a): The rainfall over Indochina Peninsula in subtropics is triggered earlier than over East China in mid-latitudes at similar longitudes in response to solar heating, and the differential diabatic heating maximum over the Indochina Peninsula (IC in the figure) may induce an anomalous equatorward flow (Fig. 10g). The magnitude of large-scale prevailing westerly is more enhanced than morning (compare with Fig. 11d). A diurnal maximum of rainfall is occurring over the Philippines with the local onshore flow due to strong land heating.

Evening (Fig. 11b): Over the Philippines, the afternoon convection is weakened but the vertical wind shear has lead to an extensive cloud shield extending over the South China Sea with a convection-induced cold pool (shown, but not well simulated in the CNTRL). The delayed peak phase of differential heating over the eastern Tibetan Plateau and the East Asia land mass occurs at this time, and the associated large-scale flow component is tending to decrease the prevailing westerlies over the South China Sea.

Night (Fig. 11c): The magnitude of mesoscale offshore breeze across the west coast of Philippines reaches a maximum at night ( $\sim 02$ LT; Fig. 6 b) due to the differential cooling between Philippines and the surrounding sea plus the effect of the convection-induced cold pool (Fig. 6c). The East Asia land mass and the Plateau are now in its cooling cycle with the downslope motion and a tendency for increasing westerly winds over the South China Sea.

Morning (Fig. 11d): Although the local offshore flow is weakening due to a weaker land-sea differential cooling, low-level convergence is a maximum due to interaction with the large-scale westerlies that have increased after the maximum cooling of the Asian continent and the Tibetan Plateau introduced an anomalous westerly wind component over the South China Sea. Thus, the increased morningtime large-scale westerly winds interact with the mesoscale offshore flow off the Philippines west coast, and the multiscale interaction of the these two diurnal circulations induces an enhanced low-level convergence that forces convective updrafts and maximum rainfall during the morning over the eastern South China Sea in these WWB events. 
The morning rainfall maximum off the west coast of Philippines (Sect. 4) has been shown to be a general feature during the active WWBs days by Ho et al. (2008). The associated afternoon minimum of infrared brightness temperature (Sect. 4) has been documented by Chen and Takahashi (1995). The diurnal variations of rainfall and infrared brightness temperature during the specific WWB case are consistent with the previous studies, which involved long-term analyses. Since the selected WWB case has diurnal variations of large-scale circulation and rainfall that are similar to the general WWB cases, the diurnal forcing mechanism is considered to be applicable since a local diurnal circulation in vicinity of Philippines exists every day following a regular solar diurnal cycle. A similar large-scale diurnal variation as in this case (Sect. 5.4) is present in Fig. 6 in Chow and Chan (2009), who analyzed the seasonal-mean diurnal variation of the large-scale circulation based on 10 years of ECMWF analyses. Since the current findings and conclusions are obtained from the analysis and simulation during a well-representative WWB case, this study contributes to broaden our understanding of diurnal circulations leading to rainfall during the WWB.

The large-scale westerlies are absent and formation of deep convection tends to be suppressed over the South China Sea during the reverse phase of the WWB period (Chen and Takahashi 1995; Ho et al. 2008). In that phase, the local diurnal circulation in vicinity of Philippines is expected to be the critical factor to induce the diurnal variation of rainfall. Since this study is to understand diurnal rainfall mechanism during the WWB cases, the differences between the active and inactive WWBs cases are beyond the scope of this research. This is an interesting scientific question, and may be studied in future research.

It is well known that mesoscale diurnal circulation such as land and sea breezes and convection-induced cold pool dynamics may be a crucial factor in coastal rainfall (Houze et al. 1981; Yang and Slingo 2001; Mori et al. 2004; Ichikawa and Yasunari 2006; and many others). The global climate model and RCM may have difficulty predicting these heavy rainfall events offshore of a coastal region because of the importance of diurnal forcing on both the local mesoscale circulation and the large-scale circulation, especially that component forced over steep, elevated terrain. The diurnal variation over the coastal regions has been improperly represented in many global-scale models. Dai and Trenberth (2004) found difficulties in properly simulating diurnal variations of rainfall, in particular over coastal regions, in the Community Climate System Model. Chow and Chan (2009) have attempted to simulate the diurnal variations over the entire Asia region in a RCM simulation with a horizontal revolution of about $60 \mathrm{~km}$. While the diurnal variation of rainfall over the southern flank of Tibet Plateau was predicted, their model did not predict the diurnal variation of coastal rainfall over South Asia.

Sato et al. (2009) analyzed the diurnal cycle of precipitation simulated in a global cloud-resolving model, and their 30-day integration successfully simulates the precipitation diurnal cycle associated with the land-sea breeze and the thermally induced topographic circulations as well as the horizontal propagation of the diurnal cycle signals. This study is consistent with Sato et al. (2009) in the sense of showing that high-resolution models are a promising tool for realistically simulating the effect of the mesoscale diurnal circulation on the diurnal variation of rainfall.

This study has not simulated all of the mesoscale dynamics that may contribute the nighttime offshore breeze and the differential cooling between land and sea: land-sea differential radiative cooling (i.e., land breeze); mountaininduced, thermally driven slope breeze; and a cold pool produced by the evaporation of rain from deep convection in a MCS. Investigation of all of these mesoscale dynamical and physical processes requires a numerical model with higher resolution than the CNTRL experiment, and this should be done with numerical sensitivity tests that will reveal the relative contributions of the various processes.

Acknowledgments This work was funded by the Korea Meteorological Administration Research and Development Program under grant CATER 2006-4204. The first author was supported by BK21 project in Korea, and the last author is supported by the Office of Naval Research Marine Meteorology section. The first author specially acknowledges valuable scientific comments by Prof. ChungHsiung Sui and Dr. Joo-Hong Kim. The study was performed during the first author's PhD course at the Seoul National University, Korea, and the manuscript was finalized during her National Research Council post-doctoral appointment at the Naval Postgraduate School, USA.

Open Access This article is distributed under the terms of the Creative Commons Attribution Noncommercial License which permits any noncommercial use, distribution, and reproduction in any medium, provided the original author(s) and source are credited.

\section{Appendix: grid nudging}

Newtonian relaxation, or nudging, is a continuous data assimilation method that relaxes the model state toward the observed state by adding to one or more of the prognostic equations artificial tendency terms based on the difference between the two states (Stauffer and Seaman 1994). In particular, the nudging toward gridded analyses based on synoptic observations or global model analyses and interpolated to model's current time step is referred as "grid nudging."

In general, the nudging (relaxation) term is treated as follows: 
$\frac{\partial A}{\partial t}=F(A, x, t)+\alpha\left(A_{\text {ref }}-A\right)$,

where the model's physical forcing terms are represented by $F$ and $A$ is the model output of atmospheric variables, $x$ are the independent spatial variables, and $t$ is time. The second term on the right side represents the nudging term and $A_{\text {ref }}$ is the reference state of atmospheric variables such as the horizontal winds, temperature, and specific humidity to which the model output A is nudged. The larger the value of $\alpha$, the more closely the forecast will follow the reference state. The $\alpha$ value used in this study is $2.5 \times 10^{-4}$.

The primary hypothesis of this study is that the diurnal variation of large-scale winds contributes to a morning diurnal rainfall maxima over the South China Sea, so this large-scale diurnal forcing should persist during the entire integration period in the current MM5 simulations. In this study, the MM5 simulation with grid nudging method is applied in which the six-hourly horizontal wind fields from the NCEP/NCAR reanalysis is used as $\mathrm{A}_{\text {ref }}$. A separate simulation without applying grid nudging did not predict the observed diurnal variation of rainfall.

\section{References}

Chakraborty A, Krishnamurti TN (2008) Improved forecasts of the diurnal cycle in the tropics using multiple global models. Part II: Asian summer monsoon. J Clim 21:4045-4067

Chen TC, Takahashi K (1995) Diurnal-variation of outgoing longwave radiation in the vicinity of the South China Sea-effect of intraseasonal oscillation. Mon Weather Rev 123:566-577

Chen TC, Yen MC, Weng SP (2000) Interaction between the summer monsoons in East Asia and the South China Sea: intraseasonal monsoon modes. J Atmos Sci 57:1373-1392

Choi YS, Ho CH (2006) Radiative effect of cirrus with different optical properties over the tropics in MODIS and CERES observations. Geophys Res Lett 33:L21811. doi:10.1029/2006 GL027403

Chow KC, Chan JCL (2009) Diurnal variations of circulation and precipitation in the vicinity of the Tibetan Plateau in early summer. Clim Dyn 32:55-73

Dai A, Trenberth KE (2004) The diurnal cycle and its depiction in the community climate system model. J Clim 17:930-951

Ho CH, Park MS, Choi YS, Takayabu YN (2008) Relationship between intraseasonal oscillation and diurnal variation of summer rainfall over the South China Sea. Geophys Res Lett 35:L03701. doi:10.1029/2007GL031962

Hong SY, Pan HL (1996) Nonlocal boundary layer vertical diffusion in a medium-range forecast model. Mon Weather Rev 124:2322-2339

Houze RA (2004) Mesoscale convective systems. Rev Geophys 42:RG4003. doi:10.1029/2004RG000150

Houze RA, Geotis SG, Marks FD, West AK (1981) Winter monsoon convection in the vicinity of north Borneo. Part I. Structure and time-variation of the clouds and precipitation. Mon Weather Rev 109:1595-1614

Hoyos CD, Webster PJ (2007) The role of intraseasonal variability in the nature of Asian monsoon precipitation. J Clim 20:4402-4424
Huffman GJ, Adler RF, Bolvin DT, Gu GJ, Nelkin EJ, Bowman KP, Hong Y, Stocker EF, Wolff DB (2007) The TRMM multisatellite precipitation analysis (TMPA): quasi-global, multiyear, combined-sensor precipitation estimates at fine scales. J Hydrometeorol 8:38-55

Ichikawa H, Yasunari T (2006) Time-space characteristics of diurnal rainfall over Borneo and surrounding oceans as observed by TRMM-PR. J Clim 19:1238-1260

Kain JS, Fritsch JM (1992) The role of convective "trigger function" in numerical forecasts of mesoscale convective systems. Meteor Atmos Phys 49:93-106

Kalnay E, Kanamitsu M, Kistler R, Collins W, Deaven D, Gandin L, Iredell M, Saha S, White G, Woollen J, Zhu Y, Chelliah M, Ebisuzaki W, Higgins W, Janowiak J, Mo KC, Ropelewski C, Wang J, Leetmaa A, Reynolds R, Jenne R, Joseph D (1996) The NCEP/NCAR 40-year reanalysis project. Bull Am Meteor Soc 77:437-471

Kiladis GN, Meehl GA, Weickmann KM (1994) Large-scale circulation associated with westerly wind bursts and deep convection over the western equatorial Pacific. J Geophys Res 99:18527-18544

Krishnamurti TN, Kishtawal CM (2000) A pronounced continentalscale diurnal mode of the Asian summer monsoon. Mon Weather Rev 128:462-473

Lau KM, Kim KM, Yang S (2000) Dynamical and boundary forcing characteristics of regional components of the Asian summer monsoon. J Clim 13:2461-2482

Loveland TR, Merchant JW, Brown JF, Ohlen DO, Reed BC, Olson P, Hutchinson J (1995) Seasonal land-cover regions of the United States. Ann Assoc Am Geogr 85:339-355

Madden RA, Julian PR (1972) Description of global-scale circulation cells in tropics with a 40-50 day period. J Atmos Sci 29: 1109-1123

Mahrer Y, Pielke RA (1977) Effects of topography on sea and land breezes in a 2-dimensional numerical-model. Mon Weather Rev 105:1151-1162

Mapes BE, Warner TT, Xu M, Negri AJ (2003a) Diurnal patterns of rainfall in northwestern South America. Part I: observations and context. Mon Weather Rev 131:799-812

Mapes BE, Warner TT, Xu M (2003b) Diurnal patterns of rainfall in northwestern South America. Part III: diurnal gravity waves and nocturnal convection offshore. Mon Weather Rev 131:830-844

Mori S, Jun-Ichi H, Tauhid YI, Yamanaka MD (2004) Diurnal landsea rainfall peak migration over Sumatera Island, Indonesian maritime continent, observed by TRMM satellite and intensive rawinsonde soundings. Mon Weather Rev 132:2021-2039

Nakazawa T (2006) Madden-Julian oscillation activity and typhoon landfall on Japan in 2004. SOLA 2:136-139

Ohasawa T, Ueda H, Hayashi T, Watanabe T, Matsumoto J (2001) Diurnal variations of convective activity and rainfall in tropical Asia. J Meteor Soc Japan 79:333-352

Oki T, Musiake K (1994) Seasonal change of the diurnal cycle of precipitation over Japan and Malaysia. J Appl Meteorol 33:1445-1463

Park MS, Choi YS, Ho CH, Sui CH, Park SK, Ahn MH (2007) Regional cloud characteristics over the tropical northwestern pacific as revealed by tropical rainfall measuring mission (TRMM) precipitation radar and TRMM microwave imager. J Geophys Res 112:D05209. doi:10.1029/2006JD007437

Ramage CS (1952) Diurnal variation of summer rainfall over east China, Korea and Japan. J Atmos Sci 9:83-86

Sapiano MRP, Arkin PA (2009) An intercomparison and validation of high-resolution satellite precipitation estimates with 3-hourly gauge data. J Hydrometeorol 10:149-166

Sato T, Miura H, Satoh M, Takayabu YN, Wang YQ (2009) Diurnal cycle of precipitation in the tropics simulated in a global cloudresolving model. J Clim 22:4809-4826 
Shige S, Takayabu YN, Tao WK, Johnson DE (2004) Spectral retrieval of latent heating profiles from TRMM PR data. Part I: Development of a model-based algorithm. J Appl Meteorol 43:1095-1113

Stauffer R, Seaman L (1994) On multi-scale four-dimensional data assimilation. J Appl Meteorol 33:416-434

Sui CH, Lau KM (1992) Multiscale phenomena in the tropical atmosphere over the western Pacific. Mon Weather Rev 120:407-430

Wang B (2006) The Asian monsoon. Springer \& Praxis Publishing, New York, p 787

Xie SP, Xu HM, Saji NH, Wang YQ, Liu WT (2006) Role of narrow mountains in large-scale organization of Asian monsoon convection. J Clim 19:3420-3429
Yamamoto MK, Furuzawa FA, Higuchi A, Nakamura K (2008) Comparison of diurnal variations in precipitation systems observed by TRMM PR, TMI, and VIRS. J Clim 21:4011-4028

Yang GY, Slingo J (2001) The diurnal cycle in the tropics. Mon Weather Rev 129:784-801

Yang S, Smith EA (2006) Mechanisms for diurnal variability of global tropical rainfall observed from TRMM. J Clim 19:5190-5226

Yoo SH, Ho CH, Yang S, Choi HJ, Jhun JG (2004) Influences of tropical western and extratropical Pacific SST on east and southeast Asian climate in the summers of 1993-94. J Clim 17:2673-2687 